\title{
Total antioxidant and oxidant status in obese children without insulin resistance
}

\author{
Insülin direnci olmayan obez çocuklarda total antioksidan ve oksidanların durumu
}

\author{
Ayşegül Doğan Demir ${ }^{1}$, Ufuk Erenberk ${ }^{1}$, İlker Tolga Özgen ${ }^{2}$, Emin Özkaya $^{3}$, \\ Aysel Vahapoğlu Türkmen', M. Ruşen Dündaröz ${ }^{1}$, Özcan Erel ${ }^{4}$
}

\section{ABSTRACT}

Objective: Oxidative stress in obese children may lead in adulthood serious conditions such as coronary heart diseases or type 2 diabetes mellitus. In childhood oxidative stress is associated with insulin resistance or extreme obesity. In this study, we aimed to evaluate oxidative stress status in moderately obese children without insulin resistance.

Methods: A total of 38 obese children (21 male, $17 \mathrm{fe}-$ male) without insulin resistance, mean aged 9.4 43.8 years) and 51 normal weight children (25 male, 26 female) as the control group, mean aged $9.3 \pm 3.9$ years) were enrolled to the study. Total oxidative status (TOS), total antioxidant capacity (TAC) were measured and oxidative stress index (OSI) was calculated.

Results: The results reveal that obese children had lower TAC than normal weight children $(2,27 \pm 0,28$ vs. $2.76 \pm 0.35 \mathrm{mmol}$ Trolox Eq./L; $p<0,001)$. There was no statistical difference between obese and control groups regarding TOS $\left(6,08 \pm 3,63\right.$ vs $5.25 \pm 4.16 \mu \mathrm{mol} \mathrm{H}_{2} \mathrm{O}_{2}$ Eq./L; $\mathrm{p}=0.333)$. OSI was higher in obese group (2.65 \pm 1.52 vs $1.92 \pm 1.56 ; p=0.029$ )

Conclusion: Balance between oxidant and antioxidant system is disrupted due to the reduced TAC even in moderately obese children without insulin resistance. Further studies should also be performed to evaluate the beneficial effects of dietary intake of antioxidants in these children.

Key words: children, obesity, oxidative stress

\section{ÖZET}

Amaç: Obez çocuklardaki oksidatif stres, erişkin dönemde koroner kalp hastalıkları veya tip 2 diyabet gibi ciddi durumlara öncülük edebilir. Çocukluktaki oksidatif stres insülin direnci veya ileri derece obezite ile ilişkilidir. Biz bu çalışmada, insulin direnci olmayan orta düzeyde obez çocuklarda oksidatif stres durumunu değerlendirmeyi amaçladık.

Yöntemler: İnsülin direnci olmayan 38 obez çocuk (21 erkek, $17 \mathrm{kız}$, ortalama yaş $9,4 \pm 3,8 \mathrm{yıl})$ ve kontrol grubu olarak 51 normal ağırlıklı çocuk (25 erkek, 26 kız, ortalama yaş 9,3 $\pm 3,9$ yıl) çalışmaya alındı. Total oksidatif durum (TOD), total antioksidan kapasite (TAK) ölçüldü ve oksidatif stres indeksi (OSi) hesaplandı.

Bulgular: Sonuçlar obez çocukların normal ağırlıklı çocuklardan daha düşük TAK'a sahip olduğunu ortaya koydu $(2,27 \pm 0,28$ ve 2,76 $\pm 0,35 \mathrm{mmol}$ Trolox Eq./L; $p<0,001)$. Obez ve kontrol grup arasında TOD'da istatistiksel olarak anlamlı fark yoktu $(6,08 \pm 3,63$ ve $5,25 \pm 4,16 \mu \mathrm{mol}$ $\mathrm{H}_{2} \mathrm{O}_{2}$ Eq./L; $\left.p=0,333\right)$. OSi obez grupta daha yüksekti $(2,65 \pm 1,52$ ve $1,92 \pm 1,56 ; p=0,029)$.

Sonuçlar: İnsülin direnci olmayan orta derece obez çocuklarda bile azalmış TAK nedeniyle oksidan ve antioksidan sistem arasındaki denge bozulmuştur. Bu çocuklarda antioksidanların diyetle alımının faydalı etkilerini değerlendirmek için başka çalışmalara intiyaç vardır.

Anahtar kelimeler: çocuk, obezite, oksidatif stres

${ }^{1}$ Bezmi Alem Vakif University Faculty of Medicine, Department of Pediatrics, Istanbul

${ }^{2}$ Bezmi Alem Vakif University Faculty of Medicine, Department of Pediatrics, Division of Pediatric Endocrinology, Istanbul

${ }^{3}$ Bezmi Alem Vakif University Faculty of Medicine, Department of Pediatrics, Division of Pediatric Allergy, Istanbul

${ }^{4}$ Yıldirım Beyazıt University Faculty of Medicine, Department of Medical Biochemistry, Istanbul

Yazışma Adresi /Correspondence: Ayşegül Doğan Demir,

Bezmi Alem Vakif University Faculty of Medicine, Department of Pediatrics, Istanbul Email: ayseguldogandemir@gmail.com

Geliş Tarihi / Received: 24.01.2014, Kabul Tarihi / Accepted: 08.05.2014

Copyright @ Dicle Tıp Dergisi 2014, Her hakkı saklıdır / All rights reserved 


\section{INTRODUCTION}

Obesity is an increasing problem around the world and it is blamed to be one of the major causes of some serious diseases such as diabetes mellitus or cardiovascular diseases [1,2]. It has been supposed that oxidative stress which was induced by obesity may have a role in pathogenesis of these obesity related diseases [3]. There are a few studies demonstrating oxidative stress in childhood. Recently, disrupted homeostatic balance between oxidantantioxidant state in obese children and adolescents with metabolic syndrome has been demonstrated [4]. It has been shown that extreme pediatric obesity, compared to milder forms of adiposity and normal weight, is associated with higher levels of oxidized low-density lipoprotein, C-reactive protein, and interleukin-6 so it was concluded that obesity related oxidative stress and inflammation exist even in younger population [5]. We also previously demonstrated that obese children have lower glutathione peroxidase and higher nitrite/nitrate levels and they were exposed to oxidative stress more than normal weight children [6].

Oxidative stress is defined as an imbalance between oxidants and antioxidants or disruption of redox signaling and control [7]. Oxidized molecules may form new radicals leading to radical chain reaction or they are neutralized by antioxidants [8]. In previous studies performed in childhood, different parts of oxidant and antioxidant systems were evaluated separately but these are complex systems and assessment of total oxidant status (TOS), total antioxidants capacity (TAC) and balance between them may have more value than assessment of one part of these systems. This new system was studied in some clinical conditions such as coronary diseases [9]. Therefore, we aimed to evaluate TOS, TAC, oxidative stress index (OSI) to assess balance between oxidative and anti-oxidative systems in obese children without insulin resistance in this study.

\section{METHODS}

After an appropriate institutional review board approved the study, parents were informed. A total of 38 obese children ( 21 male, 17 female; the mean age $9.42 \pm 3.77$ years) and 51 normal weight children as a control group (25 male, 26 female; the mean age $9.29 \pm 3.87$ years) were enrolled in the study. Control group was recruited among the healthy children who were admitted to the pediatric clinics for routine yearly examination. The participants underwent a detailed physical examination (including evaluation for specific syndromes and endocrine diseases) and laboratory evaluation (thyroid function tests and diurnal variation of cortisol). Children with syndrome (Prader Willi, Laurence-Moon-Biedle syndrome, etc.) and endocrine causes (Cushing's Syndrome, hypothyroidism, etc.) of obesity were excluded. None of the participants were using medications or had a history or evidence of current metabolic, cardiovascular, respiratory or hepatic disease. Patients under vitamin and/or mineral supplements were excluded.

Standing height $(\mathrm{cm})$ was measured to the nearest $0.1 \mathrm{~cm}$ with a Harpenden fixed stadiometer and body weight $(\mathrm{kg})$ on a SECA balance scale to the nearest $0.1 \mathrm{~kg}$, with subjects dressed in a light Tshirt and shorts. Obesity was defined as a body mass index $(\mathrm{BMI})>95^{\text {th }}$ percentile using the definition of the International Task Force of Obesity in Childhood and population-specific data [10,11]. Children were classified as moderately obese $(100-119 \%$ of the 95th percentile of BMI for age and gender) [12]

Fasting plasma glucose, serum triglyceride, total cholesterol and high-density lipoprotein -cholesterol (HDL-C), total protein, albumin, uric acid, aspartate aminotransferase (AST), alanine aminotransferase (ALT), creatinine, concentrations were measured enzymatically using an autoanalyzer (Cobas 8000, Tokyo, Japan). The LDL-cholesterol (LDL-C) level was calculated using the Friedewald equation. Fasting insulin level was measured by Siemens ADVIA Centaur classic.

Homeostasis model assessment of insulin resistance $($ HOMA-IR) index $=($ fasting insulin $(\mathrm{mU} / \mathrm{ml})$ $x$ fasting glucose $(\mathrm{mmol} / \mathrm{L}) / 22.5)$ is used as a surrogate marker of insulin resistance [13]. Insulin resistance criteria were HOMA-IR $>2.5$ for prepubertal children and HOMA-IR $>4.0$ for adolescents [14]. Children who had insulin resistance were excluded from study.

Oxidative stress was evaluated using TOS, TAC and OSI. Total oxidant status was measured with the assay based on the oxidation of ferrous ion to ferric ion in the presence of various oxidant species in acidic medium and the measurement of the 
ferric ion by xylenol orange. The assay was calibrated with hydrogen peroxide, and the results were expressed in terms of micromolar hydrogen peroxide equivalents per liter $\left(\mu \mathrm{mol} \mathrm{H}_{2} \mathrm{O}_{2}\right.$ Eq./L) [15]. Total antioxidant capacity was measured using a method developed by Erel. The results are expressed as $\mu \mathrm{mol}$ Trolox equivalent/L [8]. Oxidative stress index (OSI) value was calculated according to the following formula: OSI (arbitrary unit) $=$ TOS $(\mu \mathrm{mol}$ $\mathrm{H}_{2} \mathrm{O}_{2}$ Eq./L) / TAC (mmol Trolox Eq./L) [16].

\section{Statistics}

All statistics were performed using the program SPSS 15.0 for Windows. Student t test was used for comparing means values of age, TAC, TOS, OSI, and all biochemical parameters. Bivariate correlations were performed with Pearson's correlation tests.

\section{RESULTS}

Obese children did not differ significantly from normal-weight children in age, gender. As expected, BMI in obese group was higher than control group. Biochemical characteristics of groups were given in table 1. Serum TOS was not statistically different in obese and control group. However serum TAC and OSI were lower and higher respectively in obese group than control group (Table 1).

Table 1. Clinical and biochemical characteristics of groups and comparison of the oxidative stress parameters

\begin{tabular}{lccc}
\hline & $\begin{array}{c}\text { Obese } \\
(\mathrm{n}=38)\end{array}$ & $\begin{array}{c}\text { Control } \\
(\mathrm{n}=51)\end{array}$ & $\mathrm{p}$ \\
\hline Age (year) & $9.42 \pm 3.77$ & $9.29 \pm 2.87$ & 0.857 \\
Gender (female/male) & $17 / 21$ & $26 / 25$ & 0.669 \\
BMI (kg/m ${ }^{2)}$ & $27.63 \pm 4.72$ & $17.42 \pm 3.11$ & $<0.001$ \\
Glucose (mg/dl) & $94.11 \pm 15.79$ & $91.72 \pm 7.85$ & 0.351 \\
Insulin (U/L) & $9.7 \pm 2.22$ & $6.66 \pm 1.99$ & 0.152 \\
HOMA-IR & $2.25 \pm 1.02$ & $1.50 \pm 0.82$ & 0.112 \\
Uric acid (mg/dl) & $4.52 \pm 1.19$ & $4.68 \pm 1.03$ & 0.517 \\
Albumin (g/dl) & $4.57 \pm 0.29$ & $4.40 \pm 0.43$ & 0.168 \\
Total cholesterol (mg/dl) & $149.41 \pm 28.23$ & $142.64 \pm 18.53$ & 0.176 \\
Triglycerides (mg/dl) & $104.26 \pm 65.72$ & $79.72 \pm 29.34$ & 0.020 \\
LDL-C (mg/dl) & $97.42 \pm 23.66$ & $88.86 \pm 19.30$ & 0.064 \\
HDL-C (mg/dl) & $42.48 \pm 14.09$ & $38.66 \pm 10.03$ & 0.139 \\
TAC (mmol Trolox Eq/l) & $2.27 \pm 0.28$ & $2.76 \pm 0.35$ & $<0.001$ \\
TOS (mmol Trolox Eq/l) & $6.08 \pm 3.63$ & $5.25 \pm 4.16$ & 0.333 \\
OSI (arbitrary unit) & $2.65 \pm 1.52$ & $1.92 \pm 1.56$ & 0.029 \\
\hline
\end{tabular}

BMI: body mass index, HOMA-IR: Homeostasis model assessment of insulin resistance, LDL-C: low-density lipoprotein cholesterol, HDL-C: highdensity lipoprotein cholesterol, TAC: Total antioxidant capacity, TOS: Total oxidative status, OSI: Oxidative stress index $=($ TOS / TAC $)$
Bivariate correlations demonstrated that TAC was correlated negatively with BMI (r:-585, $\mathrm{p}<0,001)$. There was not any other correlation between TAC and biochemical parameters including albumin and uric acid. Serum TOS and OSI were not correlated with any parameters listed in Table 1.

\section{DISCUSSION}

The main result of this study was that the TAC in obese children was lower than controls. Molnar et al have also demonstrated that TAC was reduced in obese children especially with metabolic syndrome and they have commented that obese children with metabolic syndrome are prone to oxidative stress [17]. We suggested the reduced TAC may be due to feeding habits of these obese children. Previously it has been reported that diet quality of obese children is poor [18] and micronutrient status may be altered in this group [19]. Puchau et al have reported that the BMI, standard deviation score of BMI and total body fat were inversely associated with dietary TAC in obese subjects [20]. Many studies report the ability of the dietary intake to modulate antioxidant status after the acute consumption of antioxidant rich foods [21-24]. However, Lavine has commented that if dietary intake of antioxidant is sufficient, it may be possible that antioxidant metabolism or absorption may be altered [25]. In this study we demonstrated that TAC was reduced even in moderately obese patients. Therefore it must be recommended to obese children to consume some products containing more antioxidants.

The presence of oxidative stress has been evaluated previously in obese children without co-morbidities with markers of oxidative damage (malondialdehyde, and plasma carbonyl groups) by Codoñer-Franch et al [25]. In their study it has been reported that oxidative stress exist in obese children who have a BMI-SDS greater than three [26]. Moreover Karamouzis et al have demonstrated the loss of the normal homeostatic balance between oxidantantioxidant state in obese children and adolescents with metabolic syndrome [27]. Oxidative stress has been evaluated in their study by measuring plasma $15-\mathrm{F}(2 \mathrm{t})$-Isoprostane levels and protein carbonyls and a relation between metabolic syndrome and oxidative stress has been reported [27]. Correspondingly these findings, Oliver et al have also demon- 
strated that oxidative stress parameters were higher in obese children with higher BMI [28]. On the other hand Kelly et al have reported that oxidized LDL is associated with insulin resistance, independent of body fatness, in children and they suggested that oxidative stress may be independently related to the development of insulin resistance early in life [29]. We have also demonstrated that oxidative stress has a correlation with insulin resistance [6]. In these studies a large number of markers to assess oxidative stress status have been used. In our knowledge this is the first time in childhood obesity it has been evaluated with Erel method measuring total oxidant status. The second result of our study was that TOS was not statistically different between groups. All previous studies emphasize the relation between oxidative stress, insulin resistance and extreme obesity but in our study there was any insulin resistant child or extreme obese patient. Therefore we demonstrated that TOS was not affected yet in moderately obese children.

In conclusion balance between oxidant and antioxidant system is disrupted due to reduced TAC even in moderately obese children without insulin resistance. It is clear that additional studies need to research beneficial effect to increase dietary intake of antioxidants in these children.

\section{REFERENCES}

1. Centers for Disease Control and Prevention (CDC). CDC grand rounds: childhood obesity in the United States. MMWR Morb Mortal Wkly Rep 2011;21:42-46.

2. Maffeis C, Tatò L. Long-term effects of childhood obesity on morbidity and mortality. Horm Res 2001; 55:42-45.

3. Pitocco D, Zaccardi F, Di Stasio E, et al. Oxidative stress, nitric oxide, and diabetes. Rev Diabet Stud 2010;7:15-25.

4. Norris AL, Steinberger J, Steffen LM, Metzig AM, Schwarzenberg SJ, Kelly AS. Circulating oxidized LDL and inflammation in extreme pediatric obesity. Obesity (Silver Spring) 2011;19:1415-1419.

5. Karamouzis I, Pervanidou P, Berardelli et al. Enhanced oxidative stress and platelet activation combined with reduced antioxidant capacity in obese prepubertal and adolescent girls with full or partial metabolic syndrome. Horm Metab Res 2011;43:607-613.

6. Ozgen IT, Tascilar ME, Bilir P, et al . Oxidative stress in obese children and its relation with insulin resistance. J Pediatr Endocrinol Metab 2012;25:261-266.

7. Jones DP. Redefining oxidative stress. Antioxid Redox Signal 2006;8:1865-1879
8. Ozcan E. A novel automated direct measurement method for total antioxidant capacity using a new generation more stable ABTS radical cation. Clin Biochem 2004;37:277-285.

9. Aydın M, Selçok Y, Nazlı Y, et al. Relationship between total antioxidant capacity and the severity of coronary artery disease. J Clin Exp Invest 2012;3:22-28.

10. Bundak R, Furman A, Gunoz H, et al. Body mass index references for Turkish children. Acta Paediatr 2006;95:194198.

11. Cole TJ, Bellizzi MC, Flegal KM, Dietz WH. Establishing a standard definition for child overweight and obesity worldwide: international survey. BMJ 2000;320:1240-1243.

12. Marcus MD, Foster GD, El Ghormi L. Stability of relative weight category and cardiomegalic risk factors among moderately and severe obese middle school youth. Obesity (Silver Spring) 2014;22:1118-1125.

13. Matthews DR, Hosker JP, Rudenski AS, et al. Homeostasis model assessment: insulin resistance and b-cell function from fasting plasma glucose and insulin concentrations in man. Diabetologia 1985;28:412-419.

14. Valerio G, Licenziati MR, Iannuzzi A, et al. Insulin resistance and impaired glucose tolerance in obese children and adolescents from Southern Italy. Nutr Metab Cardiovasc Dis 2006;16:279-284.

15. Erel O. A new automated colorimetric method for measuring total oxidant status. Clin Biochem 2005;38:1103-1111.

16. Demirbag R, Gur M, Yilmaz R, et al. Influence of oxidative stress on the development of collateral circulation in total coronary occlusions. Int J Cardiol 2007;116:14-19.

17. Molnár D, Decsi T, Koletzko B. Reduced antioxidant status in obese children with multimetabolic syndrome. Int J Obes Relat Metab Disord 2004;28:1197-202.

18. Miller SA, Taveras EM, Rifas-Shiman SL, et al. Association between television viewing and poor diet quality in young children. Int J Pediatr Obes 2008;3:168-176.

19. Tascilar ME, Ozgen IT, Abaci A, et al. Trace elements in obese Turkish children. Biol Trace Elem Res 2011;143:188195.

20. Puchau B, Ochoa MC, Zulet MA, et al. Dietary total antioxidant capacity and obesity in children and adolescents. Int J Food Sci Nutr 2010;61:713-721.

21. Hassimotto NM, Pinto MD, Lajolo FM: Antioxidant status in humans after consumption of blackberry (Rubus fruticosus L.) juices with and without defatted milk. J Agric Food Chem 2008 ;56:11727-11733.

22. Potter AS, Foroudi S, Stamatikos A, et al. Drinking carrot juice increases total antioxidant status and decreases lipid peroxidation in adults. Nutr J 2011 24;10:96.

23. Modun D, Music I, Vukovic J, et al. The increase in human plasma antioxidant capacity after red wine consumption is due to both plasma urate and wine polyphenols. Atherosclerosis 2008; 197:250-256.

24. Pitsavos C, Panagiotakos DB, Tzima N, et al. Adherence to the Mediterranean diet is associated with total antioxidant capacity in healthy adults: the ATTICA study. Am J Clin Nutr 2005;82:694-699. 
25. Lavine JE. Relative antioxidant deficiency in obese children: A weighty contributor to morbidity? J Pediatr 1999;13:132-133.

26. Codoñer-Franch P, Boix-García L, Simó-Jordá R, et al. Is obesity associated with oxidative stress in children? Int J Pediatr Obes. 2010;5:56-63.

27. Karamouzis I, Pervanidou P, Berardelli R, et al. Enhanced oxidative stress and platelet activation combined with reduced antioxidant capacity in obese prepubertal and ado- lescent girls with full or partial metabolic syndrome. Horm Metab Res 2011;43:607-613.

28. Oliver SR, Rosa JS, Milne GL, et al. Increased oxidative stress and altered substrate metabolism in obese children. Int J Pediatr Obes 2010;5:436-444.

29. Kelly AS, Jacobs DR Jr, Sinaiko AR, et al. Relation of circulating oxidized LDL to obesity and insulin resistance in children. Pediatr Diabetes 2010;11:552-525. 